\title{
The efficiency of magnesium (Mg) on rice growth, biomass partitioning and chlorophyll contents in alkaline soil condition
}

Niaz Ahmed ${ }^{1}$, Adnan Khalil ${ }^{1}$, Allah Bakhsh Gulshan ${ }^{2}$, Safdar Bashir $^{3}$, Muhammad Saleem ${ }^{4}$, Riaz Hussain ${ }^{5}$, Muhammad Arif Ali ${ }^{1}$, Javaid Iqbal $^{6}$ and Saqib Bashir ${ }^{7 *}$

1. Department of Soil Science, Faculty of Agricultural Sciences and Technology, Bahauddin Zakariya University, Multan, Punjab-Pakistan

2. Department of Botany, Ghazi University DG Khan-Pakistan

3. Sub-campus Depalpur, University of Agriculture Faisalabad, Okara 56130, Pakistan

4. Soil and water testing Laboratory, Vehari 61100, Punjab-Pakistan

5. Mango Research Station, Shujaabad-Pakistan

6. Department of Agronomy, Ghazi University DG Khan-Pakistan

7. Department of Soil and Environmental Sciences, Ghazi University, D.G Khan-Pakistan

*Corresponding author's email: sbashir@gudgk.edu.pk

Citation

Niaz Ahmed, Adnan Khalil, Allah Bakhsh Gulshan, Safdar Bashir, Muhammad Saleem, Riaz Hussain, Muhammad Arif Ali, Javaid Iqbal and Saqib Bashir. The efficiency of magnesium $(\mathrm{Mg})$ on rice growth, biomass partitioning and chlorophyll contents in alkaline soil condition. Pure and Applied Biology. Vol. 10, Issue 1, pp325-333. http://dx.doi.org/10.19045/bspab.2021.100035

Received: 30/07/2020 Revised: 12/09/2020

Accepted: $15 / 09 / 2020$

Online First: 21/09/2020

\section{Abstract}

Magnesium (Mg) is recognized as an essential macronutrient because of its involvement in several morphological and physiological processes in numerous plant species. While, its deficiency in the soil lead to cause the severe reduction in plant growth and yield. The purpose of the current study was to evaluate the efficiency of $\mathrm{Mg}$ at (40,80 and $160 \mathrm{~kg} / \mathrm{ha}$ ) for rice growth, yield, biomass production and chlorophyll contents as well as $\mathrm{Mg}$ availability in in calcareous soil. Results demonstrated that the addition of $\mathrm{Mg}$ showed the prominent increase in rice plants vegetative growth, shoot and root fresh and dry biomass as well as enhance the availability of NPK in calcareous soil. Similarly, the significant increase in chlorophyll contents was also observed with the increasing rate of $\mathrm{Mg}$ fertilization. In conclusion, addition of $\mathrm{Mg}$ fertilizer in calcareous soils is considered an effective strategy for the rice growth.

Keywords: Alkaline soils; Chlorophyll; Magnesium; Rice; Yield

Introduction

Rice (Oryza Sativa) is recognized as one of the world's most important staple food crops; it has a major share to fulfil the food demand of the world population. According to the FAO 2016 statistics, globally rice production was more than 749 million tons, superseded by maize that accounts for 959 million tons. While, In Pakistan, Punjab and Sindh provinces have greater share in rice 
production that accounts $88 \%$ of the total country's basic food needs. Rice is cultivated on about 2.5 million hectares' area which has major share after cotton and wheat production. Recently, the cultivated land is shrinking due to the huge rise in urbanization, industrial revolution, environmental and agro climatic conditions, which pose a serious threat to is the huge world population food requirement [1].

It is interesting to address some important counter measures to increase crops yields including, well organized water conservation projects, ameliorate soil quality, innovative techniques that should be implemented to manage plant protection and fertilizers applications. The use of fertilizers is an important strategy to meet the large population food demands all around the world. However, the nutrient use efficiency was very low in Pakistani soils, especially Nitrogen $(\mathrm{N})$ and Phosphorus $(\mathrm{P}) /$ due to calcareous nature relative to European countries [2]. Therefore, the use of secondary nutrient such as $\mathrm{Mg}$ as a mixture and alone nutrient is considered the beneficial approach for rice growth and yield.

Magnesium $(\mathrm{Mg})$ is recognized an essential nutrient for various living organisms including, plant species, animals and as well as human beings [17] and thereby its deficiency may cause the reduction in sustainable agricultural production and negative impacts on other organisms [13]. Several edible agricultural products have the sufficient amount of $\mathrm{Mg}$ for humans and animals. Thus, it's an important task to maintain the quantity of $\mathrm{Mg}$ in agricultural products within sufficient amount. Unfortunately, noticeable symptoms of $\mathrm{Mg}$ deficiency often occur in edible plants, especially at their vital developmental stage with fast carbohydrate accumulation, which is widely grown in acidic soils across the world [17].
The solubility of $\mathrm{Mg}$ in the soils and its uptake by crops depends on several factors such as soil texture, agronomic practices, cation exchange capacity and plants types $[8,14]$. The sufficient amount of $\mathrm{Mg}$ in the soil is considered a key to promote crop growth and development. The availability of $\mathrm{Mg}$ in soils depends on its main four forms including, exchangeable, replaceable, complexation with natural organic substances and auxiliary structures [11].

Magnesium ( $\mathrm{Mg}$ ) deficiency in farmlands and its availability to plants is become a considerable problem because of chlorosis in the interveinal parts of leaf and induce reduction in photosynthetic pigments in plants leaves [10]. Chlorosis is a most noticeable reaction of crops to identify the $\mathrm{Mg}$ deficiency that results the reduction in sugar transport from the source to sink organs and biomass accumulation to the root and reproductive tissues $[4,8,22]$. The chlorosis development requires former degradation of chlorophyll, since $\mathrm{Mg}$ acts as a vital element in the chlorophyll molecule. When $\mathrm{Mg}$ is strongly bound to this molecule chlorosis appears to be a late response to $\mathrm{Mg}$ deficiency.

Recently, more attention has been paid on the primary macronutrients $\mathrm{N}, \mathrm{P}$ and $\mathrm{K}$ related fertilizers than secondary nutrients $\mathrm{Ca}, \mathrm{Mg}$ and $\mathrm{S}$ to attain maximum crops yield $[4,22]$. While, there is also little information is available regarding the significant importance of $\mathrm{Mg}$ for agricultural production, contribution in plant structure and physiological attributes as well as its deficiency in farmlands and crops [1, 4]. However, it is essential to recognize the behavior of crop yield to Mg-fertilization under various soils types, cropping pattern, and fertilizer management strategies in large-scale field experiments. There has been no effort made to examine the effects of $\mathrm{Mg}$ as a fertilizer on rice growth and development. In this study, a meta-analysis 
was conducted to (1) examine the overall impacts of $\mathrm{Mg}$ applications on rice yield and subsequent agronomic efficiencies; (2) To understand the effects of $\mathrm{Mg}$ fertilization on the photosynthetic rate of rice plants in alkaline condition.

\section{Materials and Methods \\ Experimental particulars}

The impact of $\mathrm{Mg}$ on rice crop growth and yield was investigated by conducting a field trial at the Research site of College of agriculture, Bahauddin Zakariya University, Multan. The research site was organized with Randomized Complete Block Design (RCBD). The research site was divided and managed into small plots with $5 \mathrm{~m}$ length and $2 \mathrm{~m}$ width. Super Basmati rice was selected as a test plant, seeds were sown in the month of July, 2018. Rice nursery was transplanted manually. The experimental units were amended with $\mathrm{MgSO}_{4}$ at the following doses: (T1), Control; (T2), $40 \mathrm{Kg}$ Mg/ ha; (T3), $80 \mathrm{Kg} \mathrm{Mg/ha;} \mathrm{(T4),} 160 \mathrm{Kg}$ $\mathrm{Mg} / \mathrm{ha}$ along with the basic application of NPK fertilizers. Super Basmati Punjab II rice variety was selected as a test crop. Recommended dose of NPK (75:76:60 kg/ ha) fertilizer was added from the sources of Urea, MOP and DAP, respectively at the time of seedling transplantation. The physico-chemical properties were presented in the (Table 1).

\section{Growth and yield attributes}

Plant height in $(\mathrm{cm})$ was measured by taking plants above ground biomass to the tip of the panicle at the time maturity and harvesting stage using meter rod. Similarly, other crop growth and yield attributes were measured including, number of tillers $\left(\mathrm{m}^{-2}\right)$, shoot diameter $(\mathrm{cm})$, thousand grain fresh weight $(\mathrm{g})$, thousand grain dry weight $(\mathrm{g})$, total grain yield $(\mathrm{kg} / \mathrm{ha})$, fresh shoot weight $(\mathrm{g})$ and dry shoot weight (g).

\section{Soil analysis}

Soil $\mathrm{pH}$ and EC were measured using the 1:2.5 and 1:5 of experimental soil and water ratio, after the harvesting of crop using $\mathrm{pH}$ and EC meter [4-6]. Soil organic matter was calculated using the wet oxidation method by taking $1.0 \mathrm{~g}$ of studied air dried soil sample [5]. The available phosphorus concentration was also determined by taking $5.0 \mathrm{~g}$ of tested soil into plastic sample tubes and add $15 \mathrm{ml}$ of $0.5 \mathrm{M} \mathrm{NaHCO}_{3}$ extractant. The soil sample was shaken and centrifuge at $3000 \mathrm{rpm}$ [5]. Extractable soil Potassium was estimated by extracting the $2.0 \mathrm{~g}$ of studied soil with the $10 \mathrm{ml}$ of $1 \mathrm{~N} \mathrm{C}_{2} \mathrm{H}_{7} \mathrm{NO}_{2}$ solution with 1:5 ratios. Then the suspension was shaken for 30 minutes at 200 to 300 rpm. The extractable $\mathrm{K}$ contents from studied soil were estimated using the flame. A calibration curve was developed which showed the $\mathrm{K}$ levels. Exchangeable $\mathrm{Mg}$ from studied soil was measured using the normal ammonium acetate extraction method. Extraction was taken and an aliquot was titrated using EDTA solution and extractable $\mathrm{Mg}$ contents were determined using atomic absorption spectrophotometer.

\section{Plant analysis}

Harvested plant tissues were collected, dried and ground for chemical analysis. Fresh plants leaves were used for chlorophyll analysis. The dried and ground portion of $1 \mathrm{~g}$ of rice plant tissues were digested using Diacid (2:1) $\left(\mathrm{HNO}_{3}+\mathrm{HCl}_{2}\right)[4,5]$. Similarly, N contents from rice tissues were measured using $0.25 \mathrm{~g}$ of rice tissues (root and leaf) and were taken in sample digesting tube with $2 \mathrm{ml}$ of $\mathrm{H}_{2} \mathrm{SO}_{4}[4,6]$. Then $30 \%$ pure Hydrogen peroxide was added and digested plant tissues at $100{ }^{0} \mathrm{C}$ for 20 minutes [3]. Phosphorus contents in rice tissues were measured by the following method [20]. We took $0.05 \mathrm{ml}$ of digesting plant sample and took $0.025 \mathrm{ml}$ of grain sample was diluted in $0.950 \mathrm{ml} 0.975$ distilled water. Finally, 0.2 $\mathrm{ml}$ of the reagent 1 was added into tubes and left the suspension for 15 minutes. 


\section{Statistical analysis}

The subjected parameters were analysed by using their means with the software (statistics 8.1). Analysis of variance (ANOVA) technique was used for the respective statistical analysis (RCBD). The least significant difference (LSD) test was used $\mathrm{p} \leq 0.05$ to understand the mean difference among the amended doses of $\mathrm{Mg}$.

\section{Results}

\section{Effect of Magnesium on rice growth, yield} and soil

The results recorded from the present study showed a significant $(\mathrm{P} \leq 0.05)$ (Table $2 \& 3)$ effectiveness of $\mathrm{Mg}$ on rice growth and yield as well as $\mathrm{Mg}$ availability in soil. Results showed that the efficiency of $\mathrm{Mg}$ along with the basal levels of NPK has the significant improvements in rice growth parameters relative to the experimental unit which were not amended with $\mathrm{Mg}$. The prominent increment in the number of plants per square meter was observed by (18.3) in T4 after the addition of $\mathrm{Mg}$ at $160 \mathrm{~kg} / \mathrm{ha}$ ). Similarly, the maximum number of spikelet plants ${ }^{-1}$ were calculated in T4 (13), while the minimum was recorded in $\mathrm{T} 1$ (9.7). The prominent increment in plant height was recorded by enhancing the levels of magnesium. Likewise, the greater increase in plant height was obtained in T4 $(69.7 \mathrm{~cm})$ relative to $\mathrm{T} 1$ $(54.0 \mathrm{~cm})$.

Data regarding the number of thousand grain weight was significantly differed after $\mathrm{Mg}$ incorporation. Then statistical observation showed that Mg play an important role to improve the weight of thousand grain. The greater increment in grain weight was recorded $\mathrm{Mg}$ was applied at $160 \mathrm{~kg} / \mathrm{ha}$ by (27.3 g) compared to T1 by (23.4 g) (Table 1). The significant difference in shoot dry biomass and diameter was recorded in the highest rate of $\mathrm{Mg}$ treated soil. The maximum shoot dry biomass and diameter was recorded by $57.3 \mathrm{~g}$ and $13.3 \mathrm{~cm}$ respectively. The SPAD values regarding chlorophyll contents were altered with the various $\mathrm{Mg}$ levels (Table 4). The greater values were recorded in $\mathrm{T} 4$ by $(0.23 \mathrm{mg} / \mathrm{g})$ where the application of $\mathrm{Mg}$ was applied at $160 \mathrm{~kg} / \mathrm{ha}$ dose, while the minimum contents were observed in $\mathrm{T} 1$ by $(0.15 \mathrm{mg} / \mathrm{g})$ where minimum Mg was applied (Table 4).

Role of $\mathrm{MgSO}_{4}$ on organic matter and $\mathrm{Mg}$ availability in soil

Soil organic matter was effectively altered after the incorporation of Mg fertilizer (Fig. 1). The greater amount of OM was estimated under T4 by $0.91 \%$, while the low contents were measured in T1 by $0.68 \%$. The greater increase in $\mathrm{Mg}$ contents were recorded in the soil, where the application of $\mathrm{Mg}$ was applied in $\mathrm{T} 448.7 \mathrm{mg} / \mathrm{g}$ while minimum was observed in T1 by $21.6 \mathrm{mg} / \mathrm{g}$, where no Mg was applied.

\section{Effect of Mg on NPK contents}

The accumulation of nitrogen $(\mathrm{N})$, phosphrous $(\mathrm{P})$ and Potassium $(\mathrm{K})$ in rice shoot was significantly altered $(\mathrm{P} \leq 0.05)$ among the treatments (Table $4 \& 5$ ). The highest $\mathrm{N}, \mathrm{P}$ and $\mathrm{K}$ contents was calculated in rice shoot in T4 by $1.29,0.24$ and $155 \mathrm{mg}$ $\mathrm{kg}^{-1}$ respectively, while low $\mathrm{N}, \mathrm{P}$ and $\mathrm{K}$ contents were recorded in $\mathrm{T} 1$ by $0.74,0.2$ and $129 \mathrm{mg} \mathrm{kg}^{-1}$ respectively. Data about the contents of $\mathrm{N}, \mathrm{P}$ and $\mathrm{K}$ in rice grains was significantly altered $(\mathrm{P} \leq 0.05)$ (Table $4 \& 5)$. The maximum $\mathrm{N}, \mathrm{P}$ and $\mathrm{K}$ contents were determined in rice grain in T4 0.76, 0.37 and $69 \mathrm{mg} \mathrm{kg}^{-1}$ respectively, while the minimum were measured in T1 $0.19,0.27$ and $57.3 \mathrm{mg}$ $\mathrm{kg}^{-1} \quad$ respectively. Similarly, highest concentration of $\mathrm{N}, \mathrm{P}$ and $\mathrm{K}$ was determined in rice leaf in treatment $\mathrm{T} 4$ by1.052, 0.33 and $165 \mathrm{mg} \mathrm{kg}^{-1}$ where $\mathrm{Mg}$ level was maximum, while minimum $\mathrm{Mg}$ dose was determined in control treatment $\mathrm{T} 1$ by 0.86 , 0.26 and $136 \mathrm{mg} \mathrm{kg}^{-1}$ respectively. 
Table 1. Selected basic physico-chemical properties

\begin{tabular}{|c|c|c|}
\hline Properties of soil & Values & Units \\
\hline Sand & 28 & $\%$ \\
Silt & 50 & $\%$ \\
Clay & 22 & $\%$ \\
\hline Textural Class & Silt loam & - \\
\hline $\mathrm{pH}$ & 8.11 & $\mathrm{dS} / \mathrm{m}$ \\
\hline $\mathrm{EC}$ & 2.1 & $\mathrm{mg} / \mathrm{kg}$ \\
\hline $\mathrm{Mg}$ & 21.23 & $\mathrm{mg} / \mathrm{kg}$ \\
\hline $\mathrm{K}$ & 161 & $\mathrm{mg} / \mathrm{kg}$ \\
\hline $\mathrm{P}$ & 4.98 & $\%$ \\
\hline
\end{tabular}

Table 2. Effect of treatments on plant growth attributes; T1 (Control), T2 (40 kg Mg/ha), T3 (80 kg Mg/ha), T4 (160 kg Mg/ha)

\begin{tabular}{|c|c|c|c|c|c|c|}
\hline Treatments & Plant height & No. of Plants & No. of Spiklets & Spike length & No. of Tillers & 1000-grain weight \\
\hline T1 & $54.0 \mathrm{~B}$ & $15.0 \mathrm{~B}$ & $9.7 \mathrm{~B}$ & $9.3 \mathrm{~B}$ & $11.0 \mathrm{C}$ & $23.4 \mathrm{C}$ \\
\hline $\mathrm{T} 2$ & $55.3 \mathrm{~B}$ & $15.7 \mathrm{~B}$ & $10.7 \mathrm{~B}$ & $10.8 \mathrm{AB}$ & $12.0 \mathrm{~B}$ & $25.1 \mathrm{BC}$ \\
\hline $\mathrm{T} 3$ & $58.3 \mathrm{~B}$ & $18.0 \mathrm{~A}$ & $11.3 \mathrm{AB}$ & $11.0 \mathrm{AB}$ & $13.3 \mathrm{AB}$ & $25.7 \mathrm{AB}$ \\
\hline T4 & $69.7 \mathrm{~A}$ & $18.3 \mathrm{~A}$ & $13.0 \mathrm{~A}$ & $12.0 \mathrm{~A}$ & $14.7 \mathrm{~A}$ & $27.3 \mathrm{~A}$ \\
\hline
\end{tabular}

Table 3. Effect of treatments on plant growth attributes; T1 (Control), T2 (40 kg Mg/ha), T3 (80 kg Mg/ha), T4 (160 kg Mg/ha)

\begin{tabular}{|c|c|c|c|c|c|c|}
\hline Treatments & $\begin{array}{c}\text { Shoot fresh } \\
\text { weight (g/plant) }\end{array}$ & $\begin{array}{c}\text { Shoot dry } \\
\text { weight (g/ Plant) }\end{array}$ & $\begin{array}{c}\text { Shoot } \\
\text { diameter }(\mathbf{c m})\end{array}$ & $\begin{array}{c}\text { Biological } \\
\text { yield (t/ha) }\end{array}$ & Chl & $\begin{array}{c}\text { Grain yield/ } \\
\text { ton }\end{array}$ \\
\hline $\mathrm{T} 1$ & $81.1 \mathrm{D}$ & $44.4 \mathrm{C}$ & $9.7 \mathrm{C}$ & $6.1 \mathrm{~B}$ & $0.15 \mathrm{~B}$ & $2.2 \mathrm{~B}$ \\
\hline $\mathrm{T} 2$ & $85.0 \mathrm{C}$ & $47.2 \mathrm{C}$ & $12.0 \mathrm{~B}$ & $6.2 \mathrm{~B}$ & $0.16 \mathrm{~B}$ & $2.3 \mathrm{~B}$ \\
\hline $\mathrm{T} 3$ & $95.7 \mathrm{~B}$ & $50.8 \mathrm{~B}$ & $12.7 \mathrm{~B}$ & $6.4 \mathrm{AB}$ & $0.22 \mathrm{~A}$ & $2.9 \mathrm{~A}$ \\
\hline $\mathrm{T} 4$ & $99.4 \mathrm{~A}$ & $57.3 \mathrm{~A}$ & $13.3 \mathrm{~A}$ & $6.6 \mathrm{~A}$ & $0.23 \mathrm{~A}$ & $3.3 \mathrm{~A}$ \\
\hline
\end{tabular}

Table 4. Effect of treatments on Magnesium and Nitrogen accumulation in plant tissues and soil; T1 (Control), T2 ( $40 \mathrm{~kg} \mathrm{Mg} / \mathrm{ha}), \mathrm{T3}$ ( $80 \mathrm{~kg} \mathrm{Mg} / \mathrm{ha}), \mathrm{T} 4$ (160 kg Mg/ha)

\begin{tabular}{|c|c|c|c|c|c|c|c|c|}
\hline \multirow{2}{*}{ Treatments } & \multirow{2}{*}{ Soil } & \multicolumn{4}{|c|}{ Mg $\mathbf{( m g} / \mathbf{k g})$} & \multicolumn{3}{|c|}{$\mathbf{N}(\mathbf{m g} / \mathbf{k g})$} \\
\cline { 3 - 9 } & & Shoot & Leaf & Grain & Soil & Shoot & Leaf & Grain \\
\hline T1 & $21.6 \mathrm{D}$ & $13.9 \mathrm{D}$ & $20.5 \mathrm{D}$ & $12.8 \mathrm{D}$ & $0.19 \mathrm{D}$ & $0.74 \mathrm{~B}$ & $0.86 \mathrm{~B}$ & $0.59 \mathrm{~B}$ \\
\hline $\mathrm{T} 2$ & $33.5 \mathrm{C}$ & $19.3 \mathrm{C}$ & $35.9 \mathrm{C}$ & $15.8 \mathrm{C}$ & $0.28 \mathrm{C}$ & $0.98 \mathrm{AB}$ & $0.95 \mathrm{AB}$ & $0.66 \mathrm{~B}$ \\
\hline $\mathrm{T} 3$ & $41.5 \mathrm{~B}$ & $25.6 \mathrm{~B}$ & $48.5 \mathrm{~B}$ & $19.9 \mathrm{~B}$ & $0.41 \mathrm{~B}$ & $1.11 \mathrm{AB}$ & $0.98 \mathrm{AB}$ & $0.69 \mathrm{~B}$ \\
\hline $\mathrm{T} 4$ & $48.7 \mathrm{~A}$ & $31.3 \mathrm{~A}$ & $60.1 \mathrm{~A}$ & $25.1 \mathrm{~A}$ & $0.61 \mathrm{~A}$ & $1.29 \mathrm{~A}$ & $1.05 \mathrm{~A}$ & $0.75 \mathrm{~A}$ \\
\hline
\end{tabular}




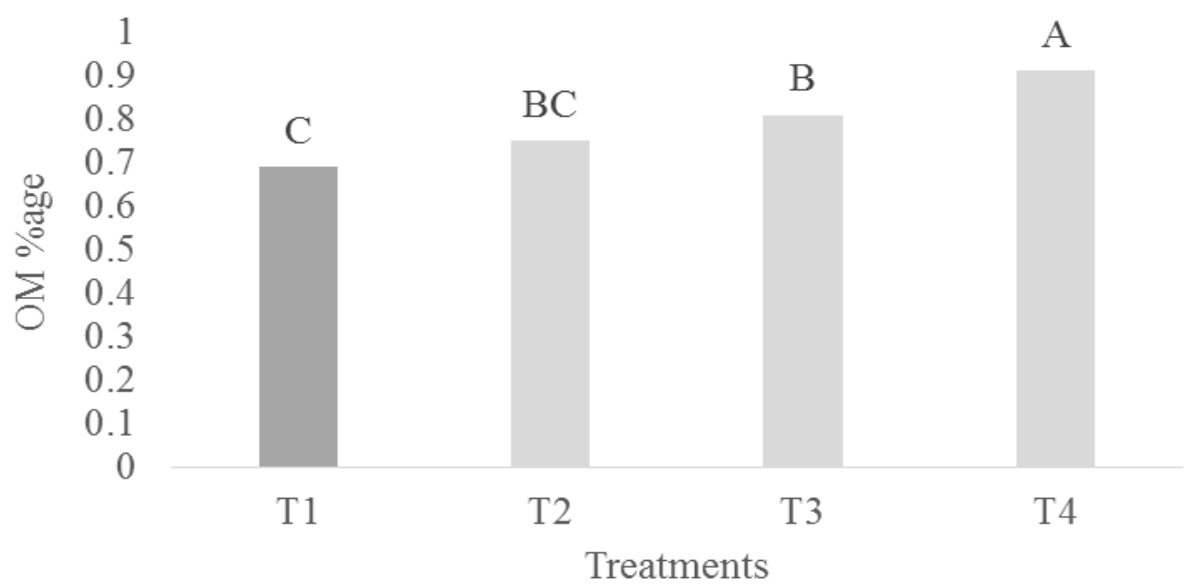

Figure 1. Effect of treatments on soil organic matter (\%age); T1 (Control), T2 (40 kg $\mathrm{Mg} / \mathrm{ha})$, T3 (80 kg Mg/ha), T4 (160 kg Mg/ha)

Table 5. Effect of treatments on Phosphorus and Potassium accumulation in plant tissues and soil; T1 (Control), T2 (40 Kg Mg/ha), T3 (80 Kg Mg/ha), T4 (160 Kg Mg/ha)

\begin{tabular}{|c|c|c|c|c|c|c|c|c|}
\hline \multirow{2}{*}{ Treatments } & \multirow{2}{*}{ Soil } & \multicolumn{4}{|c|}{$\mathbf{P}(\mathbf{m g} / \mathbf{k g})$} & \multicolumn{3}{|c|}{$\mathbf{K}(\mathbf{m g} / \mathbf{k g})$} \\
\cline { 3 - 8 } & & Shoot & Leaf & Grain & Soil & Shoot & Leaf & Grain \\
\hline T1 & $0.57 \mathrm{~B}$ & $0.19 \mathrm{~B}$ & $0.27 \mathrm{~B}$ & $0.27 \mathrm{C}$ & $18.0 \mathrm{C}$ & $128.0 \mathrm{D}$ & $135.7 \mathrm{C}$ & $57.3 \mathrm{C}$ \\
\hline $\mathrm{T} 2$ & $0.59 \mathrm{~B}$ & $0.20 \mathrm{AB}$ & $0.31 \mathrm{AB}$ & $0.31 \mathrm{~B}$ & $21.7 \mathrm{~B}$ & $137.3 \mathrm{C}$ & $161.3 \mathrm{~B}$ & $65.3 \mathrm{~B}$ \\
\hline $\mathrm{T} 3$ & $0.61 \mathrm{~A}$ & $0.22 \mathrm{AB}$ & $0.31 \mathrm{AB}$ & $0.35 \mathrm{AB}$ & $21.7 \mathrm{~B}$ & $145.0 \mathrm{~B}$ & $163.3 \mathrm{~B}$ & $68.0 \mathrm{~A}$ \\
\hline $\mathrm{T} 4$ & $0.64 \mathrm{~A}$ & $0.24 \mathrm{~A}$ & $0.33 \mathrm{~A}$ & $0.37 \mathrm{~A}$ & $25.3 \mathrm{~A}$ & $155.0 \mathrm{~A}$ & $165.0 \mathrm{~A}$ & $69.0 \mathrm{~A}$ \\
\hline
\end{tabular}

\section{Discussion}

The present study confirmed that the incorporation of $\mathrm{Mg}$ in rice plots effectively altered rice growth and yield as well as enhance soil $\mathrm{Mg}$ and organic matter contents in the soil relative to without $\mathrm{Mg}$ amended soil. The prominent increment in plant height and dry biomass after the amendments of $\mathrm{Mg}$ is also frequently documented $[20,25]$. The current study also confirmed that the addition of $\mathrm{Mg}$ at different dose levels effectively increased NPK contents in rice shoots and grains relative to without $\mathrm{Mg}$ incorporation. Similarly, the previous study described by [14], who suggested that the uptake of $\mathrm{Mg}$ by plants roots could contribute to enhance the photosynthesis, sugar contents translocation of starch, energy formation and dry biomass and plant height.

Present study suggested that the contents of $\mathrm{Mg}$ in rice grains, leaves and shoot was relatively low when rice was grown in alkaline soil without $\mathrm{Mg}$ application. The highest amount of $\mathrm{Ca}$ and $\mathrm{K}$ in calcareous soil might play role to decrease the availability of $\mathrm{Mg}$ to the rice. Likewise, [7, 10] also confirmed that both $\mathrm{Ca}$ and $\mathrm{Mg}$ has an antagonistic relationship and $\mathrm{Ca}$ effectively supress the mobility of $\mathrm{Mg}$ that led to the deficiency $\mathrm{Mg}$ in plants especially in seedling stage. It was interesting to explain that the prominent increment in $\mathrm{N}$ and $\mathrm{P}$ contents in rice grains, leaves and shoots of rice after the addition of $\mathrm{Mg}$ in calcareous soil was because of synergic 
effect of $\mathrm{N}$ and $\mathrm{P}[8,9]$. This increment might be due to the synergistic role of $\mathrm{Mg}$ with $\mathrm{N}$ and $\mathrm{P}$ in the soil.

The efficiency of magnesium in plants plays role to enhance the enzymatic activates such as nitrate reductase and sucrose-phosphate synthase, which support the better consumption of $\mathrm{N}$ and carbon [23]. The present study confirmed the addition of $\mathrm{Mg}$ showed the significant improvement in chlorophyll concentration which led to enhance the photosynthetic rate ultimately promote plant growth and yield [4]. The application of $200 \mathrm{mM} \mathrm{MgSO}_{4}$ resulted in enhancing the number of spikelet/plant [4]. A previous study suggested that with the application of magnesium enhanced the sunflower height with more efficiently with other nutrients [10]. In the current study, spike length and grains of rice were also increased after $\mathrm{Mg}$ addition. It has been reported that the maximum spike weight in barley $(1.31 \mathrm{~g})$ where maximum fertilizer applied as compare to the control treatment (1.2 g) [15].

It has been explained that the use of $\mathrm{Mg}$ for crop growth played the significant role to increase dry biomass, enhance the thickness of plant stem and root [21]. Similarly, another study proposed by [21] reported that the effect of $\mathrm{Mg}$ on maize crop yield and production that was increased with the increasing rates of $\mathrm{Mg}$ fertilizers. Results regarding the plants growth attributes revealed that the addition of $\mathrm{Mg}$ in calcareous soils showed the effectiveness to improve rice grains weight, dry shoot and root biomass, plant height and shoot diameter. These attributes also changed with climatic change.

Present study suggested that the addition of $\mathrm{Mg}$ in calcareous soils could increase the availability of $\mathrm{Mg}$ in soils for plants growth as well as $\mathrm{Mg}$ accumulation in plants tissues especially in edible portion. Several previous studies [16, 17] indicated that availability of $\mathrm{Mg}$ in calcareous soils play a vital role to promote soil fertility status as well as enhance nutrient uptake ability in plant. In the current study, the increased the level of $\mathrm{Mg}$ significantly enhance the organic matter contents in the soil [16].

\section{Conclusion}

The deficiency of $\mathrm{Mg}$ in alkaline soils seriously compromises physiological efficiency of rice plants. The fertilization of rice plants with the $\mathrm{Mg}$ source $\left(\mathrm{MgSO}_{4}\right)$ showed the prominent alteration in growth and yield. The Present study suggested that the addition of $\mathrm{Mg}$ with the basal dose of NPK in alkaline soil showed the prominent increment in rice growth and yield traits with its increasing dose. The prominent increase in chlorophyll contents were also recorded with the increasing $\mathrm{Mg}$ levels in rice crop. Several large scale studies should be performed to examine the efficacy of $\mathrm{Mg}$ fertilization by growing of various crops in calcareous soils that might have great contribution to our knowledge associated with the stressing impact of soil $\mathrm{Mg}$.

\section{Authors' contributions}

Conceived and designed the experiments: $\mathrm{N}$ Ahmad \& AB Gulshan, Performed the experiments: A Khalil \& S Danish, Analyzed the data: J Iqbal, Contributed reagents/ materials/ analysis tools: $\mathrm{R}$ Hussain \& MA Ali, Wrote the paper: S Bashir \& S Bashir.

\section{Reference}

1. Abedullah S, Kouser \& Mushtaq K (2007). Analysis of technical efficiency of rice production in punjab (Pakistan): Implications for Future Investment Strategies. Pak Econ and Soc Rev 45(2): 231-244.

2. Ahmed MK, Shaheen N, Islam MS, AlMamun H, Islam MS \& Banu CP (2015). Trace elements in two staple cereals (rice and wheat) and associated health risk implications in Bangladesh. 
Environ Monit and Asses 187(6): 326335.

3. Allen SG (1986). The effect of unionism on productivity in privately and publicly owned hospitals and nursing homes. $J$ of Labor Res 7(1): 5968.

4. Bashir S, Hussain Q, Shaaban M \& Hu $H$ (2018). Efficiency and surface characterization of different plant derived biochar for cadmium (Cd) mobility, bioaccessibility and bioavailability to Chinese cabbage in highly contaminated soil. Chemosphere. 10.1016/j.chemosphere.2018.07.168.

5. Bashir S, Shaaban M, Hussain Q, Mehmood S, Zhu J, Fu Q, Aziz O \&Hu $H$ (2018). Influence of organic and inorganic passivators on $\mathrm{Cd}$ and $\mathrm{Pb}$ stabilization and microbial biomass in a contaminated paddy soil. $J$ Soils Sediments. DOI 10.1007/s11368-0171796-z.

6. Bashir S, Zhu J, Fu Q \&Hu H (2018) Cadmium mobility, uptake and antioxidative response of water spinach (Ipomoea aquatic) under rice straw biochar, zeolite and rock phosphate as amendments. Chemosphere 194:579587.

7. Cakmak I \& Yazici AM (2010). Magnesium: a forgotten element in crop production. Better Crops 94(2): 23-25

8. Chen CT, Lee CL \& Yeh DM (2018) Effects of nitrogen, phosphorus, potassium, calcium, or magnesium deficiency on growth and photosynthesis of Eustoma. Hort Sci 53:795-798.

9. Chen ZC, Peng WT, Li J \& Liao H (2018). Functional dissection and transport mechanism of magnesium in plants. Semin. Cell Dev Biol 74: 142152.

10. Christina N, Geilfus CN \& Mühling KH (2014). Increasing root and leaf growth and yield in $\mathrm{Mg}$-deficient faba beans (Vicia faba) by $\mathrm{MgSO}_{4}$ foliar fertilization. J of Plant Nutr and Soil Sci 177(5): 741-747.

11. Gransee A \& Fu H (2013) Magnesium mobility in soils as challenge for soil and plant analysis, magnesium fertilization and root uptake under adverse growth conditions. Plant Soil 368: 5-21.

12. Hartz C, Petty P, Ouertani K, Burgado S, Lawrence C \& Kasem A (2009) Influence of iron, potassium, magnesium, and nitrogen deficiencies on the growth and development of sorghum (Sorghum bicolor L.) and sunflower (Helianthus annuus L.) seedlings. J of Biotechnol Res 1: 64-71.

13. Hermans C, Johnson GN, Strasser RJ \& Verbruggen N (2004). Physiological characterization of magnesium deficiency in sugar beet: acclimation to low magnesium differentially affects photosystems I and II. Planta 220: 344355.

14. Hossain A, Sarker M, Hakim M, Islam M \& Ali M (2013). Effect of Lime, Magnesium and Boron on Wheat (Triticum aestivum L.) and Their Residual Effects on Mungbean (Vigna radiata L.). Inter J of Agric Res, Innov and Technol 1(1-2): 9-15.

15. Lošák T, Hlušek J, Lampartová I, Mühlbachová G \& Čermák P (2017). Changes in the soil magnesium and Sulphur content after Kieserite application into Haplic Luvisol and the effect on yields of barley biomass. Acta Universitatis agriculturae et silviculturae Mendelianae Brunensis 65(4): 1225-1229.

16. Mengutay M, Ceylan Y, Kutman UB \& Cakmak I (2013). Adequate magnesium nutrition mitigates adverse effects of heat stress on maize and wheat. Plant and Soil 368(1-2): 57-72. 
17. Mikkelsen R (2010). Soil and fertilizer magnesium. Better Crops 94: 26-28.

18. Moodie CD, Smith HW \& McCreery RA (1959). Laboratory manual for Soil Fertility. Department Agronomy, State college of Washington, Pullman. pp. 3139.

19. Noor S, Akhter S, Islam M, Shil M \& Kawochar MA (2015). Effect of magnesium on crop yields within maize-green manure-T. aman rice cropping pattern on acid soil. Arch of Agron and Soil Sci 61(10): 1381-1392.

20. Ohno T \& Zibilske LM (1991). Determination of low concentration of phosphorus in soil extracts using malachite green. Soil Sci Scotish J 55: 829-895.

21. Rashid A (1986). Maping zinc fertility of soil using indicator and soil analyses. PhD Dissertation, University of Hawaii, HI, USA.
22. Sankaranarayanan K, Praharaj CS, Nalayini P, Bandyopadhyay KK \& Gopalakrishnan N (2010). Effect of magnesium, zinc, iron and boron application on yield and quality of cotton (Gossypium hirsutum). Indian $J$ of Agric Sci 80(8): 699.

23. Tatagiba SD \& Rodrigues FA (2016). Magnesium decreases the symptoms of leaf scald on rice leaves. Tropical Plant Pathol 41(2): 132-137.

24. Watanabe FA \& Olsen SR (1965). Test of an ascorbic acid method for determining phosphorus in water and $\mathrm{NaHCO} 3$ extracts from soil 1. Soil Sci Soc of America J 29(6): 677-678.

25. Zengin M, Gökmen F, Yazici M \& Gezgin S (2009). Effects of potassium, magnesium, and sulphur containing fertilizers on yield and quality of sugar beets (Beta vulgaris L.). Turkish $J$ of Agric and Fores 33(5): 495-502. 